\title{
40. MANGANESE NODULES FROM SITE 854 SEDIMENTS ${ }^{1}$
}

\author{
N.S. Skornyakova, ${ }^{2}$ T.Y. Uspenskaya, ${ }^{2}$ A.I. Gorshkov,${ }^{3}$ and A.V. Sivtsov ${ }^{3}$
}

\begin{abstract}
Two manganese $(\mathrm{Mn})$ nodules were found in upper Miocene sediments in Hole $854 \mathrm{C}$ at a depth of $32.12 \mathrm{mbsf}$ (Samples 138-854C-5H-1, 0-2 cm, and $-6 \mathrm{H}-1,2-4 \mathrm{~cm}$ ). In structure and composition, the lower nodule is similar to the Pleistocene surface nodules associated with radiolarian ooze from the Clarion-Clipperton Nodule Province. The upper nodule resembles those occurring on pelagic clay from the northern margin of that province.
\end{abstract}

\section{INTRODUCTION}

Buried ferromanganese nodules were found in the cores collected during Ocean Drilling Program (ODP) Leg 138 at Site 854. These nodules occurred in Sections 138-854C-5H-1 (32.12 mbsf) and -6H-1 (41.62 mbsf). We studied the inner structure, mineralogy, and chemistry of two nodules from these intervals.

Ferromanganese nodules have been previously recovered in many deep-sea drilling boreholes, but in most cases, these were interpreted as having fallen from above. Reliable in-situ occurrences are rare. Cronan (1973) studied nodules from Deep Sea Drilling Project (DSDP) Leg 16 boreholes, drilled in the equatorial Pacific Ocean. He showed that only nodule and crust from the lower part of Hole 162 (72.3 and $121.2 \mathrm{mbsf}$ ) are reliably in situ. These buried nodules and associated ferromanganese crust fragments are enriched in iron $(\mathrm{Fe})$ and poor in manganese $(\mathrm{Mn})$, copper $(\mathrm{Cu})$, and nickel $(\mathrm{Ni})$, thus differing from the diagenetic nodules at the seafloor surface.

The remaining nodules found in Hole 162 cores are rich in manganese, copper, and nickel, being similar to surficial ones, and may have fallen from the sediment surface to the positions in which they were found during drilling. Aumento and MacGillivray (1975) investigated the structure and chemical composition (electron microprobe) of buried nodules from the subantarctic southwestern Pacific Ocean. These nodules occurred within Miocene-Pliocene sediments and differed from those on the seafloor surface in having low contents of $\mathrm{Mn}$ and $\mathrm{Ni}$, but being somewhat enriched in cobalt (Co).

Buried nodules and crusts were found within the sediment sequences on the Wombat Plateau (northwest from Australia) during ODP Leg 122. According to De Carlo and Exon (1992), both the nodules and crusts are primarily vernadite $\left(\delta \mathrm{MnO}_{2}\right)$. They are similar chemically and mineralogically, but are dissimilar from ferromanganese deposits found elsewhere on the Australian and other marginal platforms. Three fossil Fe-Mn nodules were recovered during Leg 81 from Holes 552A, 553A, and 554A, located on the west margin of the Rockall Plateau. In the sedimentary section, these nodules are located at a level of major unconformities, in condensed sequences representing a period from early Eocene to Miocene. Investigation of these nodules (Jehanno et al., 1984) showed that the nodule from Hole 552 and micronodules from Hole 554 have been formed by poorly crystallized hydrated $\mathrm{Mn}$ oxide, mixed with $\mathrm{Fe}$-rich phases and silicates. The second type of micronodules from Hole 554 has a massive structure, with fibrous well-crystallized Mn oxides and, perhaps, is related to

${ }^{1}$ Pisias, N.G., Mayer, L.A., Janecek, T.R., Palmer-Julson, A., and van Andel, T.H. (Eds.), 1995. Proc, ODP, Sci. Results, 138: College Station, TX (Ocean Drilling Program), Russia.

P.P. Shirshov Institute of Oceanology, Russian Academy of Sciences, Moscow,

${ }^{3}$ Institute of Ore Deposits, Petrology, Mineralogy, and Geochemistry, Russian Academy of Sciences, Moscow, Russia. hydrothermal activity. The Mn-less nodule from Hole 553 is not a typical nodule that has Mn depleted by leaching, but a clay concretion that was invaded by Fe hydroxides in the sedimentary column.

\section{METHODS}

The nodules were split into two parts: one part was used for a polished section, and the other for chemical and mineralogical analyses. Bulk chemical compositions of nodules and sediments were determined using the atomic absorption method. The mineral composition was determined by means of a reflecting microscope, analytical transmission electron microscopy (the combined use of electron microscopy, selected-area electron diffraction [SAED], and electron probe microanalyses), and X-ray powder diffraction (XRD) analysis on untreated and heated samples $\left(100^{\circ} \mathrm{C}\right.$ for $\left.1 \mathrm{hr}\right)$. Investigation of internal structure and detailed sampling of individual layers and zones with known textures for mineralogical analysis were conducted in polished sections using an optical microscope. The powder samples were analyzed by a DRON-2 (CuK $\alpha$-radiation, Ni-filter, $30 \mathrm{kV}, 20 \mathrm{~mA})$.

The XRD method permits one to identify a $10-\AA$ Mn phase, birnessite (with reflections at $d=9.8,4.9,2.46,1.42$ and 7.2, 3.6, 2.46, $1.42 \AA$, respectively). If the basal reflections at $d=9.8(h k l=001)$ and $4.9 \AA(h k l=002)$ disappear after heating and two basal reflections of birnessite $(d=7.2$ and $3.6 \AA)$ appear, it means that buserite-I is in the sample. Decreasing intensity of reflections at $d(001)=9.8 / 1 \AA$ means that some other $10-\AA \mathrm{Mn}$ minerals (todorokite, buserite-II, or asbolane-buserite) are in the sample. These can only be identified by SAED. An electron microscope JEM-100C with a Kevex 5100 energy-dispersive multichannel spectrometer and semiconductor detector was used for this identification. These minerals have different structures; consequently, they are characterized by different electron diffraction patterns. The works of Chukhrov, Gorshkov, et al. (1979a, $1979 \mathrm{~b}, 1980,1983,1984$, and 1989) showed that a few Mn-minerals with different structures have the same XRD-pattern, with reflections at $d=9.8,4.9,2.44$, and $1.42 \AA$.

Todorokite, for example, has a tunnel structure; in electron microscopic photos, it is represented by lamellar particles, not infrequently with streaks from cleavage plane (100). Diffraction patterns of todorokite lamellae are, as a rule, characteristic of threefold twins, where the crystals are regularly intergrown in the plane (001), with an angle of mutual rotation of $120^{\circ}$. Depending on the degree of structural perfection in the electron diffraction patterns, reflections streak into continuous diffuse lines in the $a$-direction (Plate 1, Fig. 1).

Asbolane-buserite is an unordered mixed-layered mineral. Its structure consists of irregularly alternating asbolane and buserite (birnessite in vacuum) layers. The electron diffraction patterns of asbolane-buserite (Plate 1, Fig. 2) have noninteger series of basal reflections, expressed in the shift of a small angle reflection (001) from the site at $d=9.4 \AA$ to larger angles $(d=8.8-9.2 \AA)$. The 
Table 1. Chemical composition of buried manganese nodules and host sediments, Hole $854 \mathrm{C}$, and surface manganese nodules, Sites 3940 and 3833 .

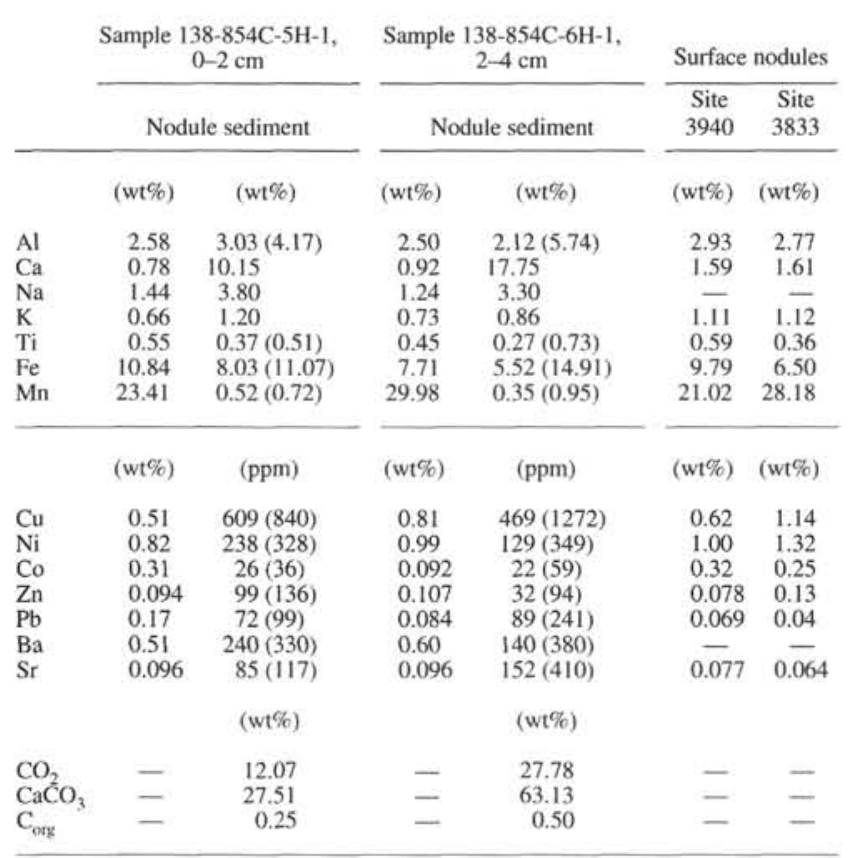

Notes: Values on carbonate-free basis are in parentheses. Dash indicates no data. Site 3940 bulk compositions of hydrogenetic nodules $(N=23)$ from pelagic clay, mineral composition consists of Fe-vernadite; site's coordinates: $20^{\circ} \mathrm{N}, 126^{\circ} \mathrm{W}$. Site 3933 bulk compositions of early diagenetic nodules $(N=41)$ from radiolarian ooze, mineral composition consists of buserite-I and asbolane-buserite; coordinates: $13^{\circ} \mathrm{N}, 132^{\circ} \mathrm{W}$.

presence of two systems of $h k 0$ reflections is caused by the existence of asbolane layers. Buserite-I and buserite-II are the structural varieties of buserite that have layer structures similar to birnessite-1 and that differ from it by $c=9.7 \AA$. The differences between the structures of buserite-I and buserite-II are in their distributive characteristics, that is, from vacant octahedral into Mn octahedral layers. Vacant octahedrals are randomly distributed in buserite-I but are bound in chains in buserite-II. Distinct from buserite-I, buserite-II does not transform into birnessite after samples have been heated and dehydration has occurred. In addition, the electron diffraction pattern of buserite-II has basal reflections at $d(001)=9.7 / 1 \AA$ (Plate 1, Fig. 3).

Iron-vernadite is established by SAED, coupled with electron probe microanalysis. It commonly gives only two reflections at $d=$ 2.4 and $1.4 \AA$ (Plate 1, Fig. 4) and, sometimes, weak reflection at $d=$ $2.2 \AA$ (for Fe-vernadite having a more ordered structure). The energydispersive microanalyses of different Fe-vernadite particles showed that noticeable variations in content of Fe can be observed.

\section{RESULTS}

\section{Sedimentological Setting}

The studied nodules occurred at 32.12 mbsf in yellowish brown, marly, nannofossil pelagic clay with zeolites and at $41.62 \mathrm{mbsf}$ in dark yellowish brown, clayey nannofossil ooze. The nodule-bearing inter$\mathrm{val}$ in Cores $138-854 \mathrm{C}-5 \mathrm{H}$ and $-6 \mathrm{H}$ is characterized, according to shipboard study, by alternating clayey nannofossil ooze, marly pelagic clay, and metalliferous clay, all enriched in Fe oxides (Mayer, Pisias, Janecek, et al., 1992; Levitan and Gurvich, this volume). The sediments directly containing the nodules are enriched in $\mathrm{Fe}$, and those at 41.62 mbsf also are rich in $\mathrm{Cu}$ (Table 1). The "excess" $\mathrm{Fe}_{2} \mathrm{O}_{3}$, calculated as total $\mathrm{Fe}_{2} \mathrm{O}_{3} \%-0.46 \mathrm{Al}_{2} \mathrm{O}_{3} \%$ (average $\mathrm{Fe}_{2} \mathrm{O}_{3} / \mathrm{Al}_{2} \mathrm{O}_{3}$ for pelagic clay; Bishoff et al., 1979) equals $8.87 \%$ at $32.12 \mathrm{mbsf}$ and $6.05 \%$ at $41.62 \mathrm{mbsf}$, presumably indicating hydrothermal influx. The hydrothermal metal supply is confirmed also by the $\mathrm{Al} \times 100 / \mathrm{Fe}$ $+\mathrm{Mn}+\mathrm{Al}$ value, which is as low as 26 , compared with 50 for the average pelagic clay.

In the composite section, the upper nodule is in a position just above a suggested hiatus between the upper Miocene and Pliocene sediments. The lower nodule (at $41.62 \mathrm{mbsf}$ ) is in the upper Miocene clayey nannofossil ooze, which is extensively bioturbated and somewhat enriched in organic carbon $\left(\mathrm{C}_{\text {org }}=0.5 \%\right.$; Table 1$)$. The clayey nannofossil ooze is underlain by dark brown pelagic clay and by metalliferous clay. Nannofossils in the nodule-bearing sediments are poorly preserved and foraminifers are absent, indicating that extensive dissolution has taken place, possibly as a result of a hydrothermal influence.

Sedimentation rates were estimated for both nodule-bearing intervals, using the shipboard paleomagnetic data (Mayer, Pisias, Janecek, et al., 1992; "Site 854" chapter). For the upper interval, we obtained a value of $1.03 \mathrm{~mm} / \mathrm{k} . \mathrm{y}$. These values are similar to those for the nodule deposits on a sediment surface.

\section{Nodules}

The nodule from $32.12 \mathrm{mbsf}$ (Section 138-854C-5H-1) is discoidal, measures $3 \mathrm{~cm}$ in diameter, and has a small surface. A fragment of the older nodule serves as a nucleus (Plate 2, Fig.1). The hydroxide crust consists of two zones: an internal one comprising alternating massive-dendritic (MD) layers with well-crystallized Mn minerals, and one of thinly laminated-dendritic (LD) layers with alternating laminae of isotropic ferromanganese, unisotropic $\mathrm{Mn}$, and black (in reflected light) clay minerals. The manganiferous part of the internal zone consists mainly of asbolane-buserite, with an admixture of buserite-II. The energy-dispersive spectra of asbolane-buserite indicate the presence of $\mathrm{Ni}$, which is a typical admixture for this mineral (Cu was not determined using this method).

The thin outer cover has a thin concentrically layered (CL) structure that results from the alternation of isotropic layers with a compact-laminated-columnar (elongated globules) structure and very thin, anisotropic $\mathrm{Mn}$ and clay laminae. The CL zone consists of asbolane-buserite and Fe-vernadite, with an admixture of buserite-I and rare particles of ferruginous X-phase. The Fe content in different particles of Fe-vernadite varies; however, as a rule, it is less than that of the Mn content.

On the basis of the chemical analysis data, the Core $138-854 \mathrm{C}-5 \mathrm{H}$ $\mathrm{Mn}$ nodule is characterized by a low $\mathrm{Mn}: \mathrm{Fe}$ ratio (2.1), enhanced $\mathrm{Co}$ and $\mathrm{Pb}$ contents ( 0.30 and 0.17 , respectively), and a low $\mathrm{Cu}: \mathrm{Ni}$ ratio $(0.62)$, which is typical for nodules from pelagic clay. The Core $138-854 \mathrm{C}-6 \mathrm{H} \mathrm{Mn}$ nodule has a small-sized $(3 \times 2 \mathrm{~cm})$, ellipsoidaldiscoidal shape, a rough surface, a distinct equatorial rim, and a cyclic, massively layered, inner structure, which is the result of the alternation of $\mathrm{MD}$ and $\mathrm{LD}$ layers (Plate 2, Fig. 2). Its outer zone consists of asbolane-buserite with an admixture of todorokite. The latter is represented by two varieties: one with $a_{0}=9.75 \AA$, and one with an unordered, mixed channel. That the asbolane-buserite has a minor admixture of buserite-II was revealed in the inner zone of the nodule. The nodule is enriched in $\mathrm{Mn}(29.98 \%), \mathrm{Cu}(0.81 \%), \mathrm{Ni}$ $(0.99 \%)$, and $\mathrm{Zn}(0.107 \%)$. The $\mathrm{Cu}: \mathrm{Ni}$ ratio is 0.82 , and the $\mathrm{Mn}: \mathrm{Fe}$ ratio is 3.9 (Table 1 ).

\section{DISCUSSION}

With regard to structural and textural features, the Mn nodule buried in Core 138-854C-5H is similar to the hydrogenetic-diagenetic type of surface nodules that have an alternation of different genetic zones (Uspenskaya and Skornyakova, 1991): the Mn nodule is hydrogenetic in the nuclear, diagenetic inner zone, which consists of MD and LD layers, and has an outer CL hydrogenetic crust. A great resemblance can be seen between this crust's mineral composition 
and the composition of the surface hydrogenetic nodule mineral (Table 1; Uspenskaya et al., 1987). Changes were observed in the inner diagenetic part of the nodule, where buserite-II appears if buserite-I is absent, with the latter being one of the dominant minerals of surface diagenetic nodules (Table 1; Uspenskaya et al., 1988). Buserite-I was not found in the Mn nodule buried in Core 138-854C-6H, although it is diagenetic according to its structure and chemical composition. In addition, both todorokite and birnessite, uncommon for the surface diagenetic nodules, were detected here.

These differences in mineral composition between buried nodules seems to be related to aging processes, which led to the transformation of buserite-I to buserite-II and todorokite. Such a transition may be considered the result of an ordering of vacancies in octahedral $[\mathrm{MnO}]_{6}$ layers in the context of structural positions. The distinctions in structure and composition of buried nodules from upper Miocene sediments of Hole $854 \mathrm{C}$ noted above are related to the environment of the seafloor and to the nodule growth mechanism. The hydrogenetic Mn nodule in Core 138-854C-5H was formed about 6.55 to 6.90 $\mathrm{Ma}$ ago on a pelagic clay surface under conditions of low sedimentation rates and low surface-water productivity $\left(\mathrm{C}_{\text {org }}\right.$ content volume in these sediments is $0.25 \%$ ).

The appearance of a diagenetic layer in the inner zone of the nodule is thought to be associated with paleoproductivity fluctuations (M.A. Levitan, pers. comm., 1993) and with a suggested increase of organic $\mathrm{C}$ content in sediments, which led to enhanced diagenetic activity and to the formation of a high-manganese layer. The diagenetic nodule in Core 138-854C-6H formed in the surface layer of clayey nannofossil ooze about $8.0 \mathrm{Ma}$ ago and also is related to enhanced paleoproductivity, which is confirmed by the increased organic C content $(0.50 \%)$ and by extensive bioturbation of the sediments that contain the nodule.

\section{REFERENCES $*$}

Aumento, F., and MacGillivray, J.M., 1975. Geochemistry of buried MiocenePleistocene ferromanganese nodules from the Antarctic Ocean. In Hayes, D.E., Frakes, L.A., et al., Init. Rept. DSDP, 28: Washington (U.S. Govt. Printing Office), 795-803.

Bischoff, J.L., Heath, G.R., and Leinen, M., 1979. Geochemistry of deep sea sediments from the Pacific Manganese nodule province: Domes Sites A, B, C. In Bishoff, J.L., and Piper, D.Z. (Eds.), Marine Geology and Oceanography of the Pacific Manganese Nodule Province: New York (Plenum), 397-436.

Chukhrov, F.V., Gorshkov, A.I., Beresovskaya, V.V., and Sivtsov, A.V., 1979a. Contribution to the mineralogy of authigenic manganese phases from marine manganese deposits. Miner. Dep., 14:249-261.
Chukhrov, F.V., Gorshkov, A.I., and Drits, V.A., 1989. The Hypergene Manganese Oxides: Moscow (Nauka). (in Russian)

Chukhrov, F.V., Gorshkov, A.I., Drits, V.A., Saharov, B.A., Uspenskaya, T.Y., and Sivtsov, A.V., 1984. The structural models and the research methods of buserite. Izv. Akad. Nauk SSSR, Ser. Geol., 10:65-74.

Chukhrov, F.V., Gorshkov, A.I., Drits, V.A., Shterenberg, L.Y., Sivtsov, A.V., and Saharov, B.A., 1983. Mix-layer minerals asbolan-buserite and asbolans in oceanic ferromanganese nodules. Izv. Akad. Nauk SSSR, Ser. Geol., 5:91-99. (in Russian)

Chukhrov, F.V., Gorshkov, A.I., Rudnitskaya, E.S., Beresovskaya, V.V., and Sivtsov, A.V., 1980. Manganese minerals in clays: a review. Clays Clay Miner., 28:346-354.

Chukhrov, F.V., Gorshkov, A.I., Sivtsov, A.V., and Beresovskaya, V.V., 1979 b. New data on natural todorotikes. Nature, 278:631-632.

Cronan, D.S., 1973. Manganese nodules in sediments cored during Leg 16, Deep Sea Drilling Project. In van Andel, T.H., Heath, G.R., Init. Repts. DSDP, 16: Washington (U.S. Govt. Printing Office), 605-608.

De Carlo, E.H., and Exon, N.F., 1992. Ferromanganese deposits from the Wombat Plateau, northwest Australia. In von Rad, U., Haq, B.U., et al., Proc. ODP, Sci. Results, 122: College Station, TX (Ocean Drilling Program), 335-345.

Jehanno, C., Lallier-Vergès, E., Bonnot-Courtois, C., Desprairies, A., Bijon, J., and Rivière, M., 1984. Fossil polymetallic concretions from Deep Sea Drilling Project Leg 81: mineralogical, geochemical, and statistical studies. In Roberts, D.G., Schnitker, D., et al., Init. Repts. DSDP, 81: Washington (U.S. Govt. Printing Office), 701-723.

Mayer, L., Pisias, N., Janecek, T., et al., 1992. Proc. ODP, Init. Repts., 138 (Pts. 1 and 2): College Station, TX (Ocean Drilling Program).

Uspenskaya, T.Y., Gorshkov, A.I., and Sivtsov, A.V., 1987. Mineralogy and internal stricture of $\mathrm{Fe}-\mathrm{Mn}$ nodules from the Clarion-Clipperton fracture zone. Int. Geol. Rev., 29:369-371.

1988. Inner structure and mineral composition of an oceanic Mn nodules. Izv. Akad. Nauk SSSR, Ser. Geol., 4:88-97. (in Russian)

Uspenskaya, T.Y., and Skornyakova, N.S., 1991. Textures and Structures of Oceanic Manganese Nodules and Crusts: Moscow (Nauka). (in Russian)

\footnotetext{
Abbreviations for names of organizations and publication titles in ODP reference lists follow the style given in Chemical Abstracts Service Source Index (published by American Chemical Society).
}

Date of initial receipt: 5 May 1993

Date of acceptance: 24 January 1994

Ms 138SR-151 

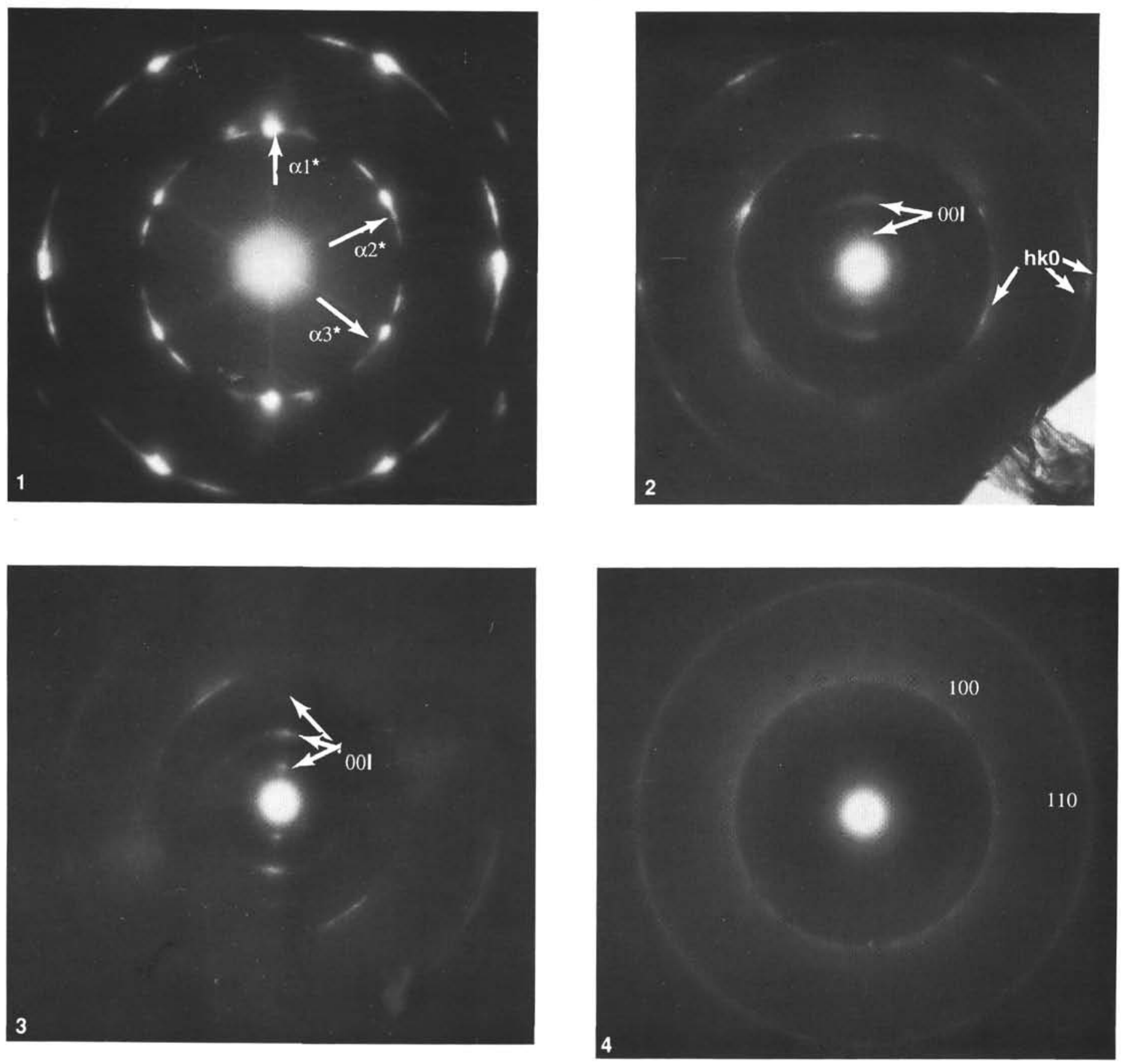

Plate 1. The selected area electron diffractions of minerals. 1. Todorokite with weak degree of structural perfection. 2. Asbolane-buserite. 3 . Buserite-II. 4. Iron-vernadite. 


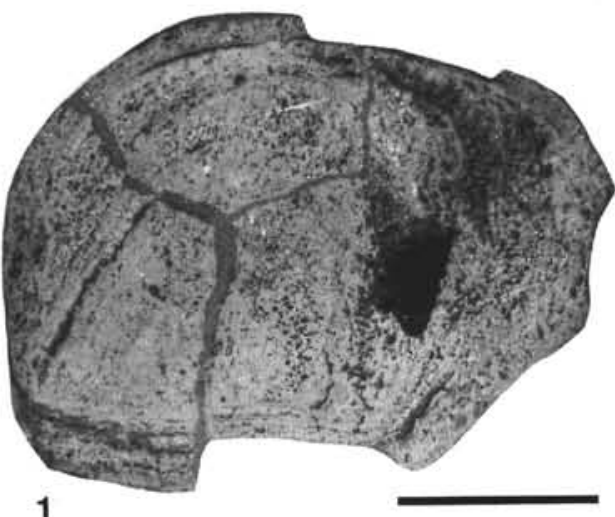

1

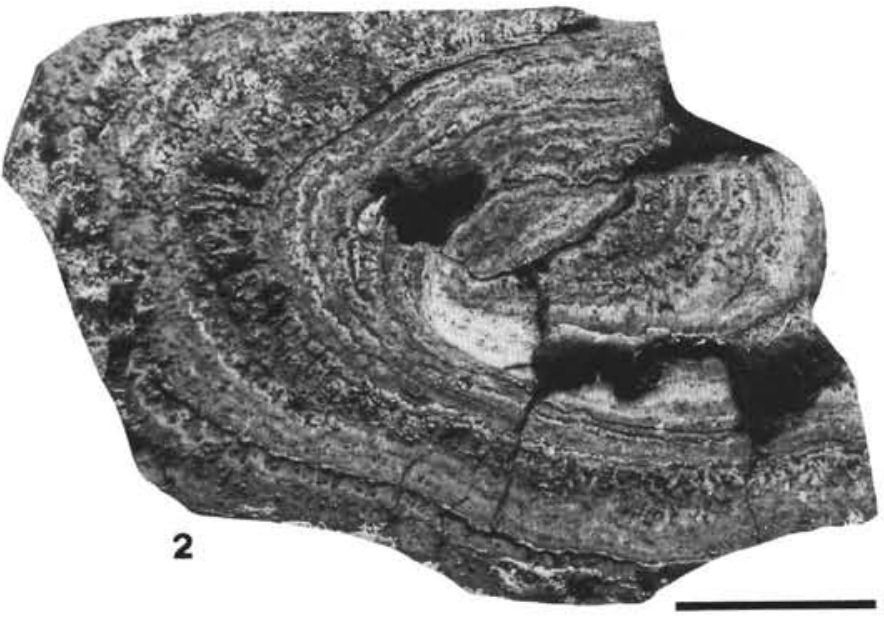

Plate 2. Polished sections of the nodules. Scale bar $=0.5 \mathrm{~cm}$. 1. Hydrogenetic/diagenetic-type nodule in Core 138-854C-5H with three growth stages. 2. Diagenetic-type nodule in Core 138-854C-6H. 